\title{
Anthropic Processes and Land-Use Change During 33 Years in Roraima, Northern Amazonia
}

\author{
Marcelle A. Urquiza ${ }^{1,2}$, Valdinar F. Melo ${ }^{3}$, Márcio R. Francelino ${ }^{4}$, Carlos E. G. R. Schaefer ${ }^{4}$, Eliana de Souza ${ }^{4}$, \\ Reinaldo I. Barbosa ${ }^{5}$, Marcelo M. Santiago ${ }^{6}$, Thiago H. de C. Araújo ${ }^{7} \&$ Soniclay da S. Maia ${ }^{8}$ \\ ${ }^{1}$ Department of Computer Science, Federal University of Roraima, Boa Vista, Roraima, Brazil \\ ${ }^{2}$ Postgraduate Program of the Amazonian Biotechnology and Biotechnology Network (BIONORTE), Federal \\ University of Roraima, Boa Vista, Roraima, Brazil \\ ${ }^{3}$ Department of Soils and Agricultural Engineering, Federal University of Roraima, Boa Vista, Roraima, Brazil \\ ${ }^{4}$ Department of Soils, Federal University of Vicosa, Viçosa, Minas Gerais, Brazil \\ ${ }^{5}$ Department of Environmental Dynamics, National Institute for Research in Amazonia, Boa Vista, Roraima, \\ Brazil \\ ${ }^{6}$ Graduate School of Geography, Federal University of Vicosa, Viçosa, Minas Gerais, Brazil \\ ${ }^{7}$ Graduate School of Agronomy, Federal University of Roraima, Boa Vista, Roraima, Brazil \\ ${ }^{8}$ Postgraduate Program in Agricultural Sciences (PÓSAGRO), Federal University of Roraima, Boa Vista, \\ Roraima, Brazil \\ Correspondence: Marcelle A. Urquiza, Department of Computer Science, Federal University of Roraima, Av. \\ Cap. Enê Garcez, 2413, Boa Vista, Roraima, Brazil. Tel: 55-095-981-125-420. E-mail: marcelle.urquiza@ufrr.br
}

Received: March 21, 2018

doi:10.5539/jas.v10n7p426
Accepted: May 2, 2018 Online Published: June 15, 2018

URL: https://doi.org/10.5539/jas.v10n7p426

\begin{abstract}
The Amazon region has experienced a rapid rate of deforestation and land use change as a result of establishment of agricultural settlements, resulting from public policies designed to promote rural development. We analyzed land use patterns and changes in the central region of Roraima, northern Brazil, testing the hypothesis that the anthropic pressure based on the conversion of natural vegetation (forest ecotone zone and open areas of savanna and campinaranas) on agriculture and pasture, has led to the decline of forest resilience, and has not promoted development in lands converted in agricultural colonization projects, a process exacerbated by practices of burning. Satellite images from between 1984 to 2017, with field-collected data and geoprocessing techniques, allowed interpretation and analysis of seven land-use classes. Agriculturally-based human impacts were greatest in forest areas, with forest loss rates being 6.4 times greater than regeneration rates. The $39.3 \%$ reduction in natural non-forest vegetation types exceeded that of forest loss (23.8\%). Repeated fires resulted in a $627.1 \%$ increase in forest fragmentation in areas heavily impacted by fire. Our study revealed that, over 33 years, deforestation and transitions of land to non-conservation uses did not lead to a system with highly productive agricultural practices, but to extensive impoverished, and degraded subsistence. The main reason was the basic unsuitability of the region's extremely acidic/dystrophic soils on which settlements have been founded, and the predominance of low-tech, family-based, agriculture and the absence of the required technology for attaining better results.
\end{abstract}

Keywords: Amazonia, deforestation, fire, forest-savanna ecotone, human impacts

\section{Introduction}

Human-based impacts in the Amazon region are both scattered and varied (Laurance, 2007), with some areas impacted for decades by deforestation (Fearnside, 2017), while others suffer the consequences of recent urbanization (Laurance et al., 2002), failure of colonization projects (Ludewigs, D’antona, Brondízio, \& Hetrick, 2009), or the expansion of cattle ranching in forested areas (Davidson et al., 2012), among others.

In Amazonia, changes resulting from occupation dynamics increased with the beginning of colonization projects and agricultural settlements (Almeida \& Campari, 1995). The concentration of people at colonization sites within forest mosaics led to high rates of deforestation, and unsustainable extraction of timber products (Nepstad 
et al., 1999), the road building (Kirby et al., 2006), and infrastructure development for income generation and offer of services (Meyfroidt, Lambin, Erb, \& Hertel, 2013).

In the central region of Roraima state, northern Brazilian Amazonia, the colonization process began in the 1980s, coordinated by the National Institute of Colonization and Agrarian Reform (INCRA), resulting in the establishment of the Apiaú agricultural colony (Barbosa \& Fearnside, 2000). The processes of land concession in general are created by markets and public policies (Lambin et al., 2001), of the interplay of a variety of agents in the social and economic milieu, which collectively give rise to urban nuclei and the changes in land-use and coverage (Mourão, 2008), as well as to different spatial arrangements (Xaud, 2013).

Among the processes involved in land-use change, and the resulting fragmentation and subsequent abandonment of these colonized lands (Diniz, Kok, Hott, Hoogstra-Klein, \& Arts, 2013) are the widespread failures of recent colonists to adequately manage and conserve their lands, due to the very low fertility of the soil (Melo, Schaefer, Fontes, Chagas, \& Lemos Júnior, 2006), and insufficient public policies supporting rural development. Together, these have combined to create high rates of abandonment among recent colonists, putting pressure on clearing new areas of native forests (Schaefer, 1997).

Meanwhile, and in contrast to the subsistence economy of the colonists, agricultural producers and ranchers have access to financial resources, fiscal incentives and technological support as a means of increasing productivity and market access, bringing an entrepreneurial approach to regional land management, and increase the collective rate of forest loss by the consolidation of agriculturally-based activities, as noted by Zarin et al. (2016). Thirty years ago Fearnside (1987) presciently predicted that this developmental strategy would have highly negative environmental impacts, and that there was no evidence increased productivity would result in forest restoration or regeneration.

In addition to the above mentioned factors, the dynamics of the impacts of fire on savannas (Barbosa \& Fearnside, 2005), and primary forests in Roraima State (Barni, Pereira, Manzi, \& Barbosa, 2015) is, in part, a reflection of the long-established culture of slash-and-burn as a form of agricultural land management (Barbosa \& Fearnside, 1999). This action has a singular impact on a local ecosystem, as it is associated with the effects of climate change (Gustavsson et al., 2017), and can increase the likelihood of extreme climatic events linked to either aridity or rainfall. Such actions can diminish environmental resilience in areas with high incidences of slopes, with shallow soils and fragmented landscapes, as well as compromising the ecological functions of natural forest/non-forest ecotones, where biologically-important areas of savanna occur (Barbosa \& Campos, 2011) and white-sand vegetation, locally known as Campinarana (Anderson, 1981).

The municipality of Mucajaí has one of the highest rates of deforestation of Roraima State. For this reason, the municipality has been part of the Plan for Prevention and Control of Deforestation in the Legal Amazon (PPCDAM) since 2009 (MMA, 2013). In that same year, 37 logging companies in Roraima extracted about 188 thousand $\mathrm{m}^{3}$ of $\operatorname{logs}$ from forests in the State, $48 \%$ of which were destined for the Legal Amazon market, 38\% for international markets and the remaining 14\% for other markets in Amazonian Brazil (MMA, 2010).

Among the tools available for monitoring deforestation (Chávez Michaelsen et al., 2017) and the space-time evolution of a landscape undergoing land-use changes, remote sensing has the potential to provide data from extensive areas (Jakimow, Griffiths, van der Linden, \& Hostert, 2018). Information available may include data on soils, relief, and the changes that human actions bring to natural formations (Lathuillière, Miranda, Bulle, Couto, \& Johnson, 2017), which can be identified and classified from images captured by satellite sensors (Clark, 2017) and made available for the study of natural resources.

Studies of the rhythm, extent, and spatial characteristics of land-use changes have been conducted the areas surrounding agricultural settlements (Almeida \& Campari, 1995; Diniz et al., 2013). Together these have allowed the identification of, factors that sustainable management of regional forests to be aligned with agricultural expansion and the opening of local markets. This has been done in ways that both permit generation of income derived from logging and forest resources, and are in-line with conservation-appropriate land-use management practices. This not only moves in step with the recently-developed paradigm of sustainable development of the Amazon region (Nobre et al., 2016), but is in keeping with government guidelines on limitation of $\mathrm{CO}_{2}$ emissions, since land-use changes (Aguiar et al., 2016; Ogle et al., 2014), are now responsible for 75\% of such emissions in Brazil, having overtaken the industrial sector of the national economy (Cerri et al., 2015; IPCC, 2007).

The hypothesis of the study was that anthropic pressure of agricultural and livestock nature towards the forest ecotone zone, the open savanna and campinaranas have given the addition of current fire-use practices, induced a decline in forest resilience and has little contribution for the development of the region. Given this, the objectives 
of the current study were to (i) quantify and qualify both spatial and temporal changes in land use occurring between 1984 and 2017, and, (ii) use this knowledge to understand the processes involved in the landscape evolution of the study area.

The official settlements aim of the study was to provide guidelines and discuss the evolution of in Amazonia, especially in ecotonal areas, as a result of spread of deforestation, the practice of largely family-based agricultural model on poor, mostly dystrophic, soils, and the minimal development of technological agriculture due to diverse social, economic and environmental constraints.

\section{Material}

\subsection{Study Area}

The study area is located in the municipality of Mucajaí (between $2^{\circ} 12^{\prime}$ and $2^{\circ} 44^{\prime} \mathrm{N}$, and $60^{\circ} 50^{\prime}$ and $61^{\circ} 36^{\prime} \mathrm{W}$, central Roraima state. A site where the process of agricultural colonization began in the 1980s. The site occurs in the Datum SIRGAS 2000 UTM zone 20N, covers an area of approximately $3257 \mathrm{~km}^{2}$, and is limited on the north by the Mucajaí and Apiaú rivers and on the west by the Branco river (Figure 1).

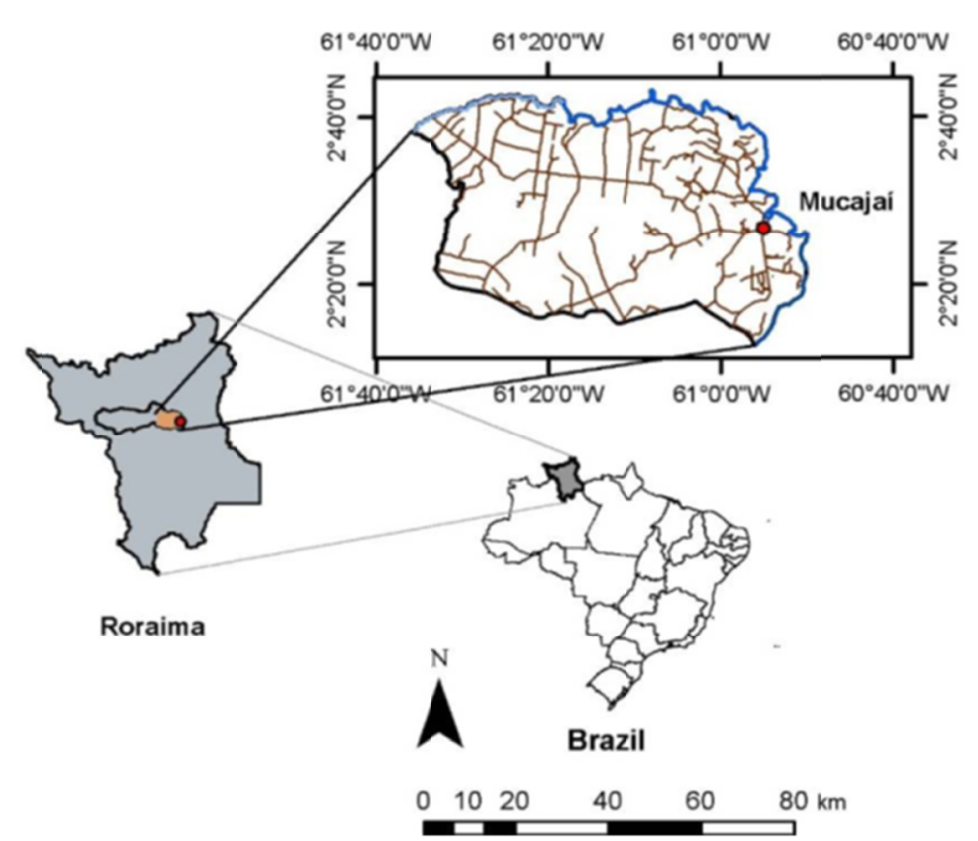

Figure 1. Location of the study area within Roraima State, northern Brazil

According to the Köppen classification system, the regional climate is of the "Ami" type, rainy tropical with a well-defined dry season from December to March, and average annual rainfall of 1700 to $2000 \mathrm{~mm}$, with the highest rainfall concentrated between the months of May and July (Barbosa, 1997). The temperature range from 22 to $34^{\circ} \mathrm{C}$ with annual average of $27^{\circ} \mathrm{C}$ (Lameira \& Coimbra, 1988).

Relief varies from flat to gentle undulating and hilly, with some areas of mountainous relief. The area is characterized by a pediplanated surface, alluvial plains, inselbergs and low mountain ranges with an elevation varying from 54 to $1450 \mathrm{~m}$ (Melo, Francelino, Fernandes Filho, \& Schaefer, 2005).

Soils are developed from deep-weathered pre-Cambrian rocks (Granites, Granodiorites, Diorites, and Migmatites) of the Guianas Complex, followed by Tertiary sediments and Quaternary clayey-sandy and sandy sediments.

Vegetation is composed of different forest types (evergreen and seasonal), which are interspersed by non-forest openings composed of savanna and campinarana (RADAMBRASIL, 1975). The area of open vegetation constitutes a very distinct sector of the savanna, but represents $0.2 \%$ of the total savanna area of Roraima State. It is an ecotonal environment, with a highly specific fauna and flora and complex geographic boundaries.

\subsection{Analytical Tools-Data Bases}

For image classification satellite images of the Landsat-5/Thematic Mapper-TM sensor satellite images from the years 1984, 1994 and 2004 and from the Operational Land Imager (OLI)/Landsat-8 (INPE, 2016) for the years 
2014 and 2017 were used. All images were obtained at no cost from the United States Geological Survey (USGS), in orthorectified mode, with a spatial resolution of $30 \mathrm{~m}$. Images were selected were those with the lowest cloud cover. From the same collection, scenes (n02_w061_1arc_v3 and n02_w062_1arc_v3) from the Shuttle Radar Topography Mission (SRTM) were selected. This digital elevation model has a raw data resolution of 1 second of arc (approximately $30 \mathrm{~m}$ ) and was obtained by processing of Digital Elevation Model (DEM) of the respective study area, in addition to using generating derived morphometric variables. We also used the IBGE Legal Amazon databases with the themes geology, geomorphology, pedology and vegetation (IBGE, 2006).

The mapping of land use classes for each year of analysis was performed using ArcGIS software, version 10.2.1, via the Basemap database available in ArcGIS, and by the Google Earth Pro platform.

\section{Methods}

\subsection{Image Classification}

Satellite images for the years 1984 (21/04), 1994 (11/01) and 2004 (11/03) were processed in composition RGB 345, and 2014 (19/02) and $2017(10 / 01)$ in composition RGB 654. A classification un-supervised by the IsoCluster method was derived, which considered 10 a priori use and ground cover classes. After classification, obtained files were reclassified and grouped into seven coverage classes, and all features were edited manually.

For the 2017 scenes, a classification supervised with Maxver algorithm (Max Likelihood) and 80 points with geographic coordinates obtained in the field were selected for the training (56 points) and validation ( 24 points) stages of classification, with samples of 4 pixels in size for each of the seven mapped classes.

Using the ArcGIS Basemap image database and the Google Earth Pro platform, from 1984 to 2017, areas with cloud and cloud shadow were reclassified and validation and confirmation of the mapped classes of use was performed, concomitantly with the observations of: 1-Forest (FLO), 2-Agriculture (AGR), 3-Natural Non-Forest Vegetation (NNFV), 4-Water Bodies (AGU), 5-Urban ( URB), 6-Other (OUT) and 7-Fire-Impacted Forest (FIF). Table 1 provides a description of the seven classes of land use mapped for each year.

Table 1. Description of classified land use classes for the years 1984, 1994, 2004, 2014 and 2017

\begin{tabular}{ll}
\hline Use Classes & Description \\
\hline Forest (FLO) & $\begin{array}{l}\text { Natural forest formations, dense forest, open forest, flooded forest, degraded forest, and } \\
\text { secondary forest. }\end{array}$ \\
Agriculture (AGR) & $\begin{array}{l}\text { Areas dedicated to agriculture, annual crops, semi-perennial crops, cultivation mosaics, grazing on } \\
\text { natural grasslands, scrubby pasture, open grasslands, degraded areas, degraded with exposed soil, } \\
\text { areas in preparation for planting, eroded and gullying areas. }\end{array}$ \\
Natural Non-Forest Vegetation (NNFV) & $\begin{array}{l}\text { Non-forest natural vegetation's, including natural non-forest wetlands, white-sand vegetation } \\
\text { (Campinarana, wooded and herb-shrub mix), savanna vegetation (short grass, grassy-woody), } \\
\text { pioneer formations (wetlands) and high-montane vegetation. }\end{array}$ \\
Water bodies (AGU) & $\begin{array}{l}\text { Rivers, streams, aquaculture ponds, reservoirs and water-tanks. } \\
\text { Commercial and residential establishments located within an urban perimeter. }\end{array}$ \\
Urban (URB) & Rock outcrops and adjacent areas (erosional plains) used for mining and recreational activity. \\
Others (OUT) & Forest areas heavily affected heavily by fire, located on slopes and crests of large hills, mountains \\
Fire-Impacted Forest (FIF) & and steep slopes with occurrence of rock outcrops. \\
\hline
\end{tabular}

Overall Accuracy Index and Kappa Index (Card, 1982; Congalton, 1991) were created for the 2017 classifications. The maps generated by the classifications were vectored and the areas quantified in hectares ha).Additionally, percentages for each of the mapped uses was calculated. All materials were produced for use at scales up to 1: 60000 .

\subsubsection{Calculation of the Overall Accuracy Index (OA) and Kappa Index (k)}

In order to evaluate the accuracy of a classification and the overall accuracy, a confusion matrix was used (Card, 1982; Congalton, 1991). Overall Accuracy $(O A)$ was calculated by dividing the sum of the samples of the main diagonal $x_{i i}$ of the confusion matrix by the total number of samples $n$ collected for each of the use classes $(c)$ :

$$
O A=\frac{\sum_{i=1}^{c} x_{i i}}{n}
$$


The confusion matrix for the 2017 scene was obtained using the Intersect command in ArcGis software. It indicates the result of comparing the classification obtained with field observations. This matrix provides information on how many pixels (or area size in hectares) were correctly sorted and how many wrongly classified. A Kappa coefficient (k) was also generated. The index estimates the accuracy of the processed classification. Six sets of OA and $\mathrm{k}$ values were generated by modifying the training samples, observing the best spectral representation for each sampled class and the distribution of the samples, given the limitations of the quantity and spatial arrangement of polygons within the mapped classes.

\subsubsection{Detecting Change}

Change detection permits identification of which transitions occurred between land-use classes, and is an important tool for understanding the changes dynamics from a temporal perspective. Transition matrices were obtained for the periods 1984/1994, 1994/2004, 2004/2014, 2014/2017 and 1984/2017.

\subsection{Acquisition of Observation Points}

To record environmental observation points, the thematic base for roads was adjusted, depending on which part of the 1984 to 2017 period was involved. A 1:100000 scale road map (IBGE, 2011) was used as reference, and five road maps were generated, based on the road updates that occurred during the study period. These were digitized on-screen from the Google Earth Pro platform.

A field survey on the study area was carried out in January 2017, and 2000 points were acquired using a GNSS receiver. The Landscapes were photographed and described for relief and land-use class.

\section{Results and Discussion}

\subsection{Spatio-temporal Evolution of Land-Use Classes}

Over the 33 year period the most notable land-use class changes mapped in the area was forest cover (FLO), with a reduction of 64970.7 ha (Table 2).

Table 2. Areas and percentages for each land use class between 1984 and 2017

\begin{tabular}{|c|c|c|c|c|c|c|c|c|c|c|c|}
\hline \multirow{2}{*}{$\mathrm{N}^{\mathrm{o}}$} & \multirow{2}{*}{ Classes } & \multicolumn{2}{|c|}{1984} & \multicolumn{2}{|c|}{1994} & \multicolumn{2}{|c|}{2004} & \multicolumn{2}{|c|}{2014} & \multicolumn{2}{|c|}{2017} \\
\hline & & ha & $\%$ & ha & $\%$ & ha & $\%$ & ha & $\%$ & ha & $\%$ \\
\hline 1 & FLO & 273420.6 & 84.0 & 255209.5 & 78.4 & 213128.3 & 65.4 & 213304.7 & 65.5 & 208449.9 & 64.0 \\
\hline 2 & AGR & 32672.1 & 10.0 & 49209.1 & 15.1 & 83360.8 & 25.6 & 89467.2 & 27.5 & 97872.4 & 30.1 \\
\hline 3 & NNFV & 15369.4 & 4.7 & 15470.7 & 4.8 & 14360.6 & 4.4 & 12412.1 & 3.8 & 9322.9 & 2.9 \\
\hline 4 & $\mathrm{AGU}$ & 3159.1 & 1.0 & 3134.4 & 1.0 & 3107.5 & 1.0 & 3651.3 & 1.1 & 3525.3 & 1.1 \\
\hline 5 & URB & 164.9 & 0.1 & 303.3 & 0.1 & 513.9 & 0.2 & 708.2 & 0.2 & 758.8 & 0.2 \\
\hline 6 & OUT & 51.7 & 0.0 & 86.4 & 0.0 & 96.4 & 0.0 & 103.4 & 0.0 & 84.3 & 0.0 \\
\hline 7 & FIF & 781.7 & 0.2 & 2130.2 & 0.7 & 11169.3 & 3.4 & 6006.9 & 1.8 & 5684.5 & 1.7 \\
\hline
\end{tabular}

Note. FLO $=$ Forest, $\mathrm{AGR}=$ Agriculture, $\mathrm{NNFV}=$ Natural Non-forest Vegetation, $\mathrm{AGU}=$ Water Bodies URB $=$ Urban, OUT $=$ Other, and FIF $=$ Fire-Impacted Forest.

Agricultural activities increased from 10\% to $30.1 \%$ between 1984 and 2017, meaning an approximately $200 \%$ increase. IBGE (2017) reported that in the Mucajaí municipality the bovine herd increased $640 \%$ between 2004 (some 20000 head), and 2016 (129000 head), revealing that this has become the main economic activity on the region, so that cattle ranching was the main reason for the forest conversion, as seen by the current study.

Expansion of agricultural activity occurred most intensively in the peripheral portions of the study area (Figures 4A, 4B, 4C, 4D and 4E), due to proximity of large rivers (Branco, Mucajaí and Apiaú), and to tributaries. Regional water availability has attracted producers, promoting various forms of agricultural development, including cultivation of sorghum, soybean and maize, where agriculturalists operated the Crop-Cattle-Forest Integrated Land Management System (ILPF). Cattle ranchers with extensive areas of land were able to maximize operate well-managed pastures that use better technology to mantain quality and productivity of the soil.

In contrast, there was also an increase of small areas, with fragments of forests connecting poor-quality and degraded pastures and many abandoned lands, generally close to main secondary roads there. Small farmers of agricultural colonization settlements deal with poor soils and no financial resources to modernize their activities. Many colonists are now of aged, and maintain agricultural activity only for their basic subsistence, with short 
crop cycles, and primitive forms of management, including the use of fire to clear secondary vegetation and renew pastures, as reported in Barros, Santos, Melo, and Lopes (2008).

A total of 101 points were mapped for different crop types (Table 3), with cassava (Manihot esculenta Crantz) and banana (Musa spp) being the most frequent (27.7\% and $24.8 \%$, respectively). The dominance of cassava shows how profoundly the extremely acidic and poor soils of the region can limit agricultural diversification (Melo et al., 2005). However, good adaptation to existing soil conditions, low operating costs and high production potential make cassava one of the most promising crops for family agriculture in the region (EMBRAPA, 2011).

Table 3. Agricultural use, number of records and percentage of sites under various forms of cultivation

\begin{tabular}{|c|c|c|c|c|c|}
\hline Land use & $\mathrm{N}^{\mathrm{O}}$ & $\%$ & Land use & $\mathrm{N}^{\mathrm{o}}$ & $\%$ \\
\hline Açaí & 1 & 1 & Crop rotation-banana & 1 & 1 \\
\hline Açaí, banana and orange & 1 & 1 & Crop rotation-corn and beans & 1 & 1 \\
\hline Banana and pineapple & 1 & 1 & Soya and corn & 1 & 1 \\
\hline Banana and açaí & 1 & 1 & Sorghum and millet & 1 & 1 \\
\hline Banana and orange & 1 & 1 & Teak & 1 & 1 \\
\hline Banana and lemon & 1 & 1 & Teak and cassava & 1 & 1 \\
\hline Banana and pasture & 1 & 1 & Tomato & 1 & 1 \\
\hline Banana (irrigated) & 1 & 1 & Pineapple & 2 & 2 \\
\hline Citrus (Orange) & 1 & 1 & Banana and cashew & 2 & 2 \\
\hline Cupuaçu & 1 & 1 & Orange & 2 & 2 \\
\hline Pasture & 1 & 1 & Lemon & 2 & 2 \\
\hline Papaya & 1 & 1 & Cassava and banana & 2 & 2 \\
\hline Cassava and cashew & 1 & 1 & Passion fruit & 2 & 2 \\
\hline Cassava and orange & 1 & 1 & Millet & 2 & 2 \\
\hline Cassava and maize & 1 & 1 & No-till soybean & 2 & 2 \\
\hline Passionfruit, papaya and banana & 1 & 1 & Traditional soybean cultivation & 2 & 2 \\
\hline Passionfruit and banana & 1 & 1 & Sorghum & 3 & 3 \\
\hline Watermelon and beans & 1 & 1 & Banana & 25 & 24.8 \\
\hline Diverse grain planting & 1 & 1 & Cassava & 28 & 27.7 \\
\hline ILPF system & 1 & 1 & Total & 101 & 100 \\
\hline
\end{tabular}

Note. $\mathrm{N}^{0}=$ Number of observations, $\%=$ Percent of observations, ILPF $=$ Integrated Crop-Cattle-Forest system.

At over half of sites (52.5\%) had a variety of planted crops, but all represent small areas, such as residential backyards. Because of this it had not been possible to identify them spectrally from the 2017 Landsat 8.0/OLI image, which had $30 \mathrm{~m}$ spatial resolution. Figure 2 shows the localities visited and cultivation sites, of which 87 were under family agriculture (Agrifam), and 24 under intensive agriculture (AgriIntens). The latter are concentrated in only three rural properties. 


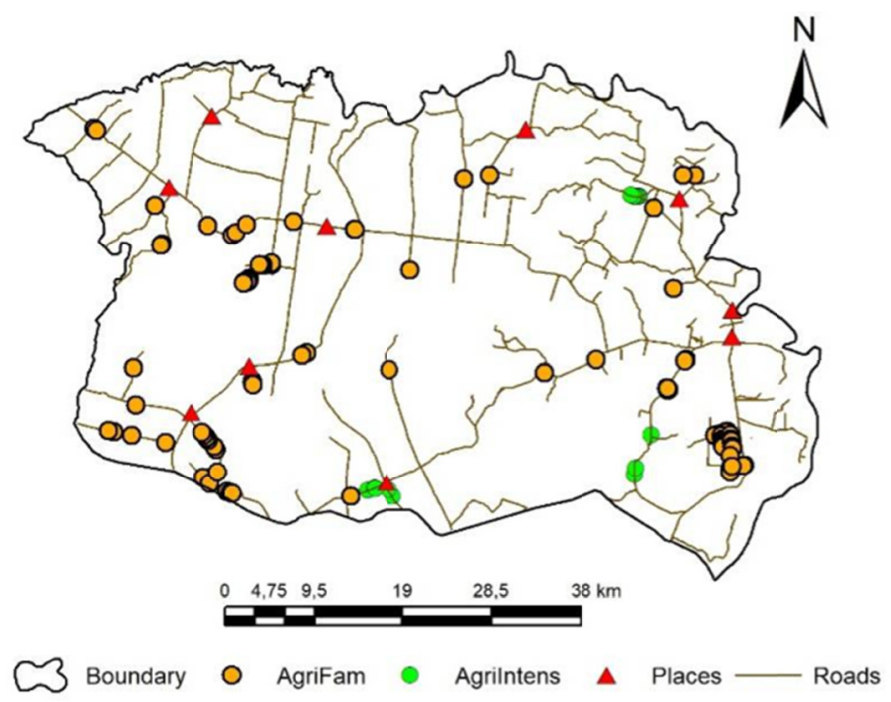

Figure 2. Location of agricultural cultivation study sites

Note. Agrifam = Family Agriculture; AgriIntens = Intensive Agriculture .

In the years 1984, 1994 and 2004 the class Water Bodies occupied 3159.10 ha, some 1\% of the study area. From 2014 the area under fish ponds increased, all used for raising Tambaqui (Colossoma macropomum), which increased this cover class by $0.1 \%$ between 2014 and 2017. However, mapping the hydrographic network and impounded areas (Figure 3) indicated that an area larger than this was being dammed within the reach of large streams (Azul, Branco, Miravel and others). The apparent stability of percentage cover for the Water Bodies class occurs because most features generated by human-mediated changes to streams and the natural watercourses, are not being counted because they are smaller than the $900 \mathrm{~m}^{2}$ pixel of the Landsat image resolution.

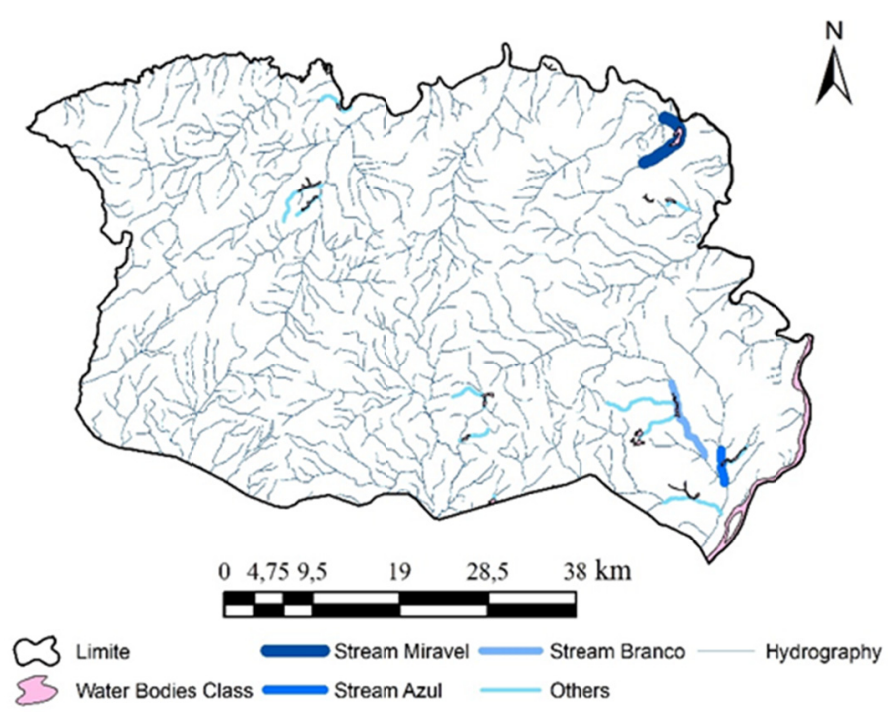

Figure 3. Map of streams altered by damming and pond construction

In the Amazon region most public-available, mapped data is only published at the 1:250000 scale, where smaller polygons are not mapped explaining the differences for Water Bodies class when comparing our 2004 data for area-use percentage (2096.2 ha-0.64\%) and that from 2014 (2122.4 ha-0.65\%) derived by the TerraClass project (Almeida et al., 2016). In our study, all land-use classes were mapped at the 1:60000 scale, allowing a four-fold gain in the capacity to detect the process of landscape change. 
The NNFV class, representing the forest ecotone zone and the savanna and campinarana mosaic, appeared practically unchanged, occupying $4.7 \%, 4.8 \%$ and $4.4 \%$ of the land in, respectively, 1984, 1994 and 2004. The observed variations of $0.1 \%$ and $0.3 \%$ of occupied area were, in part, artifacts of the classification, digitalization and manual features edition.

Such stability within the NNFV class suggests a low pressure on non-forest environments until 1994 (Figure 4B). This was probably due to the absence of big farmers with investment capacity for developing such nutrient-poor soils, at that fine.

The reduction in the cover the NNFV class began between 1994 and 2004, when it fell from 4.8\% to 4.4\%, followed by $3.8 \%$ to $2.9 \%$ in 2017 . The year 2004 set the begining of this reduction. This change probably reflects the expansion of agricultural and livestock activities into the ecotonal area, since it matches the implementation of the national policy of the Action Plan for the Prevention and Control of Deforestation in the Legal Amazon (MFP, 2013), which promoted a decline in the annual Amazon deforestation rate from 27,772 $\mathrm{km}^{2} /$ year to $5,012 \mathrm{~km}^{2}$ in 2014 (INPE, 2017a). In Mucajaí municipality, there was a reduction in deforestation from $104.58 \mathrm{~km}^{2}$ to $42.32 \mathrm{~km}^{2}$ from 2004 to 2014 (INPE, 2004). It is also worth noting that in this region there was a displacement and expansion of cattle ranching in forested areas and forest/savanna transition zone, following the expulsion of cattle ranchers from newly established indigenous reserves in Roraima (São Marcos and Raposa Serra do Sol).

The urban area (URB) grew by $460.2 \%$ in the period, rising from 164.9 ha to 758.8 ha. Currently the study region contains 10 villages and some remnants of the first agricultural colonization in the 1980s. Growth of the urban area does not reflect any great population increase, as the municipality is located $65 \mathrm{~km}$ from the capital, Boa Vista, and residents of Mucajaí mostly work in small businesses, or in rural areas. However, local rural population increased by 20\% between 2000 (4207 inhabitants) and 2010 (5857 inhabitants) (CGMA, 2015).

The class Others (OUT), varied between 51.7 ha (1984) and 84.3 ha (2017), with a $163.05 \%$ increase in rocky areas, used for gravel extraction.

The area of Fire-impacted Forests (FIF) increased by 4903.40 ha (727.83\%) between 1984 and 2017 (Figure 4), reaching 111169.30 ha in 2004 , then declining to 6006.90 ha in 2014 . This alternation of increases and decreases is mirrored in the class Forest (FLO), since FIF areas originated from the forest class, as observed in the 1984 scene, the initial year of the study. This class represents extremely fragile environments, often located on steep slopes (greater than $20 \%$ of declivity) in the domain of Cambisols (CM) and Leptosols (LP) (WRB, 2014), where rock often outcrops. The presence of shallow soils, together with steep slope (20 to $45 \%$ ) and recurrent fires have resulted in high natural erosion rates, and low resilience. This process resulted in a low open forest formation, as observed by Vieira et al. (2005) at three study sites in the Amazon basin. In addition, Mesquita, Massoca, Jakovac, Bentos, and Williamson (2015) reported that annual fires eliminated seedlings, saplings, coppice, and seeds in the soil. In a recent study Balch, Massad, Brando, Nepstad, and Curran (2013) have demonstrated for the Amazon forest in the State of Mato Grosso (Brazil) that increasing in fire frequency ( $>5$ in 6 years) led to higher mortality and less regeneration, especially in seedlings, with $85 \%$ decline in stems with small density (less than $1 \mathrm{~cm}$ ), reducing species diversity and altering the ecosystem regeneration.

The results presented and the observations made by the aforementioned works support and confirm the hypothesis that the frequent fire regime spatially determine the expression of forests impacted by fire (FIF) and contributes to the decline of forest resilience, although observations are limited to 33 years of evolution, for which centuries may be necessary (Balch et al., 2013) for attaining advanced regeneration. We also emphasize the need to monitor natural (climate, temperature and soil) and anthropogenic conditions (use of fire in land management) to enable the acceleration of regeneration processes.

Figure 4 (A, B, C, D and E) shows the spatial layout of each land-use classes mapped between the years 1984 and 2017. For the year 2017 (Figure 4E), the Kappa and Global Accuracy indices were 0.921 and 0.936 , respectively. According to Landis and Koch (1977), such values represent excellent quality land classification. 


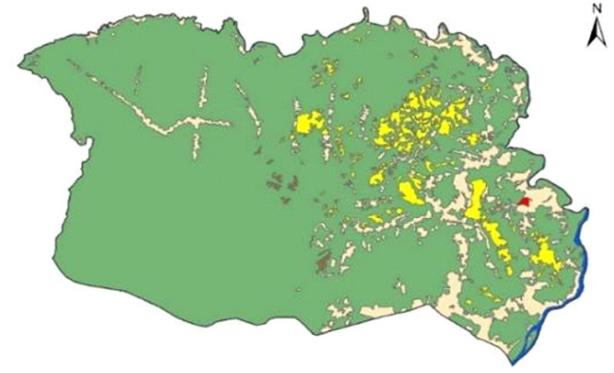

A

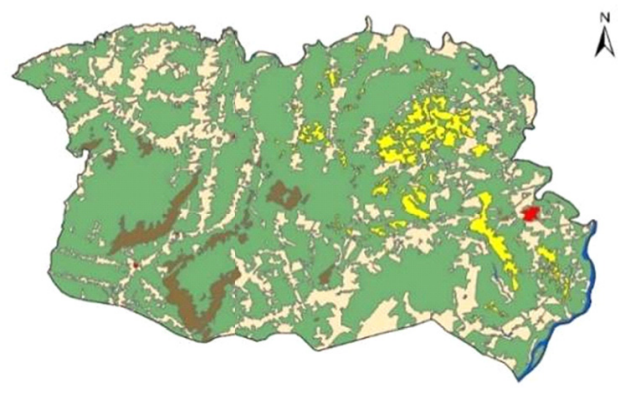

C

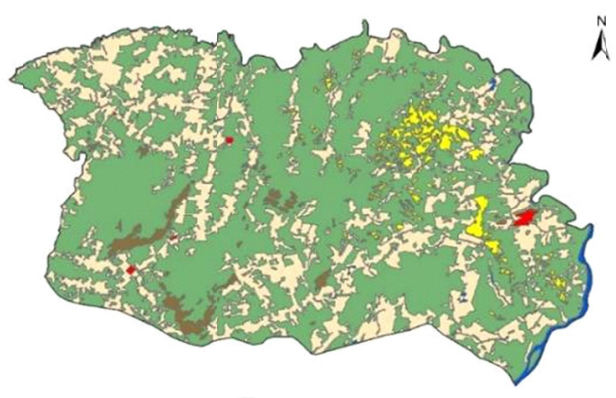

E

$\bigwedge^{N}$

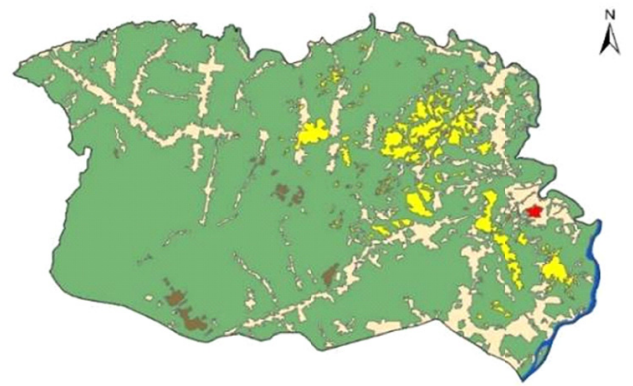

B

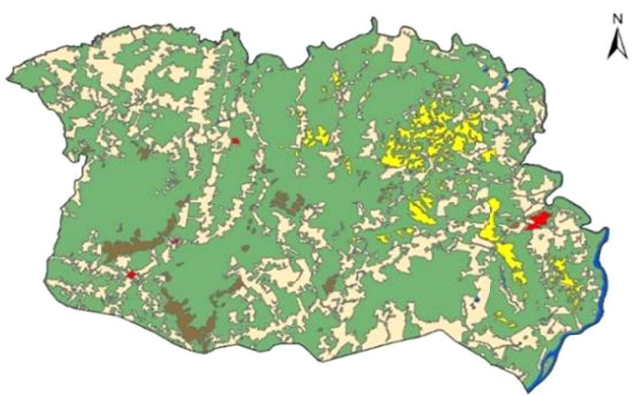

D

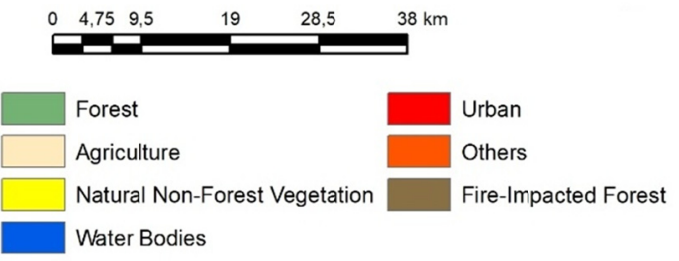

Figure 4. Land use maps: A-1984, B-1994, C-2004, D-2014, and E-2017

\subsection{Land-Use Changes}

Five matrices were generated to show the transitions occurring for each of the land-use classes on the maps from 1984/1994, 1994/2004, 2004/2014, 2014/2017 and 1984/2017.

\subsubsection{Land-Use Changes 1984 to 1994}

In the first decade studied, there was a 7:1 ratio between FLO-FIF transitions $\left(15.6 \mathrm{~km}^{2}\right)$ and FIF-FLO $\left(2.2 \mathrm{~km}^{2}\right)$, indicating a system in rapid change (Table 4), and the low resilience of this environment, given the pace of such changes. The NNFV-FLO (0.7\%) and FLO-NNFV (0.8\%) transitions, although vegetationally incompatible, occurred in part due to inherent imperfections in vector processing, as separating these features in this eco-region had a $1 \%$ error limit. During the study period, $13 \%$ of the land-use mosaic showed transitions. Conversions of FLO-AGR (7.8\%) and AGR-FLO (2.7\%) occurred in 2:9 ratio, and accounted for $82.7 \%$ of all changes occurring during the period.

However, it is also possible that the NNFV-FLO transition represents the occurrence of regeneration in regions that were originally under forest cover in the transition zone, that were impacted by humans, then abandoned and in the process of natural recovery. However, the FLO-NNFV transition represents the process of ongoing human impact in the forest areas in contact with the NNFV mosaic, so expanding the boundaries of the NNFV class. 
Table 4. Land-use transition matrix from 1984 to 1994 (area in $\mathrm{km}^{2}$ )

\begin{tabular}{|c|c|c|c|c|c|c|c|c|c|}
\hline Year & Use in 1994 & & & & & & & & \\
\hline \multirow{11}{*}{ 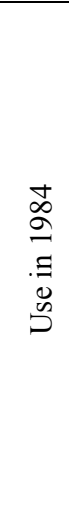 } & Class & FLO & AGR & NNFV & $\mathrm{AGU}$ & URB & OUT & FIF & Total \\
\hline & FLO & 2435.4 & 255.3 & 24.7 & 1.4 & 0.7 & 0.3 & 15.6 & 2733.5 \\
\hline & AGR & 89.5 & 233.3 & 1.7 & \multirow[t]{2}{*}{1.1} & \multirow[t]{3}{*}{0.8} & \multirow[t]{4}{*}{0.1} & \multirow[t]{5}{*}{0.1} & 326.7 \\
\hline & NNFV & 22.7 & 2.7 & 128.3 & & & & & 153.7 \\
\hline & $\mathrm{AGU}$ & 2.1 & 0.6 & & 28.7 & & & & 31.5 \\
\hline & URB & & 0.1 & & & 1.5 & & & 1.6 \\
\hline & OUT & 0.1 & & & & & 0.5 & & 0.5 \\
\hline & FIF & 2.2 & & & & & & 5.6 & 7.8 \\
\hline & Total & 2552.0 & 492.1 & 154.7 & 31.3 & 3.0 & 0.9 & 21.3 & 3255.3 \\
\hline & C $84 / 94\left(\mathrm{~km}^{2}\right)$ & -181.4 & 165.4 & 1.0 & -0.2 & 1.4 & 0.3 & 13.5 & \\
\hline & $*(\%)$ & -6.6 & 50.6 & 0.7 & -0.6 & 83.9 & 67.1 & 172.5 & \\
\hline
\end{tabular}

Note. C 84/94 $\left(\mathrm{km}^{2}\right)$ was used to calculate the modified area of each use class of use. For the FLO class, the formula (1). FLO $=(2733.5-2552.0) / 2733.5=-181.4 \mathrm{~km}^{2}$. The percentage change $*(\%)$ per class FLO was calculated with formula (2). FLO $\%=[(2733.5-2552.0) / 2733.5] 100=-6.6$.

\subsubsection{Land-Use Changes, 1994 to 2004}

In this period, transitions reached a total of $24 \%, 11 \%$ more than the previous period, and FLO-AGR transitions increased to $14.4 \%$, and those for AGR-FLO $4 \%$, occurring in the ratio of 3.6 , and accounting for $76.9 \%$ of all changes in the uses mosaic (Table 5).

The ratio between FLO-FIF $\left(9.2 \mathrm{~km}^{2}\right)$ and FIF-FLO $\left(1.6 \mathrm{~km}^{2}\right)$ transitions was 57.6 indicating an advanced change regime in comparison to the previous period, and accelerated degradation due to intense fire-related dynamics, a situation that has also occurred in the previous study period. In 2003, Mucajaí municipality had the highest number of focal fire spots $(4,661)$ in the State, which matched the municipality's high transition incidence to the class of forest affected by fire (FIF) (INPE, 2017).

Table 5. Transition Matrix for land-use between 1994 and 2004 (area in $\mathrm{km}^{2}$ )

\begin{tabular}{|c|c|c|c|c|c|c|c|c|c|}
\hline Year & Use in 2004 & & & & & & & & \\
\hline \multirow{11}{*}{ 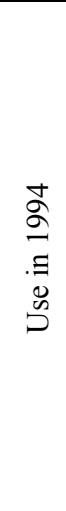 } & Class & FLO & AGR & NNFV & AGU & URB & OUT & FIF & Total \\
\hline & FLO & 1960.0 & 468.0 & 27.5 & 3.2 & 0.8 & 0.2 & 92.2 & 2552.0 \\
\hline & AGR & 129.9 & 355.0 & 2.7 & \multirow[t]{2}{*}{2.8} & \multirow[t]{3}{*}{1.4} & \multirow[t]{4}{*}{0.1} & \multirow[t]{5}{*}{0.1} & 492.0 \\
\hline & NNFV & 32.8 & 8.5 & 113.4 & & & & & 154.7 \\
\hline & $\mathrm{AGU}$ & 4.3 & 1.0 & & 25.0 & & & & 30.2 \\
\hline & URB & & 0.1 & & & 2.9 & & & 3.0 \\
\hline & OUT & 0.2 & & & & & 0.7 & & 0.9 \\
\hline & FIF & 1.6 & 0.4 & & & & & 19.3 & 21.3 \\
\hline & Total & 2128.9 & 832.9 & 143.6 & 31.0 & 5.1 & 1.0 & 111.6 & 3254.1 \\
\hline & C $94 / 04\left(\mathrm{~km}^{2}\right)$ & -423.1 & 340.9 & -11.1 & 0.8 & 2.1 & 0.1 & 90.3 & \\
\hline & $*(\%)$ & -16.6 & 69.3 & -7.2 & 2.5 & 69.5 & 11.6 & 423.9 & \\
\hline
\end{tabular}

\subsubsection{Land-Use Changes, 2004 to 2014}

Table 6 shows a further period during which human-created (AGR, AGU and URB) habitats increased (by 7.4\%, $13.7 \%$ and $37.8 \%$, respectively), suggesting a continued increase in agricultural and urbanization expansion. In addition, there was an increase of $11.2 \%$ in the AGU class compared to the previous period, which coincides with a rise in activities related to fish farming, as shown by the increase in the number of water bodies appearing on the 2004 use map (Figure 4C). 
Table 6. Transition Matrix for land-use between 2004 and 2014 (area in $\mathrm{km}^{2}$ )

\begin{tabular}{|c|c|c|c|c|c|c|c|c|c|}
\hline Year & Use in 2014 & & & & & & & & \\
\hline \multirow{11}{*}{ 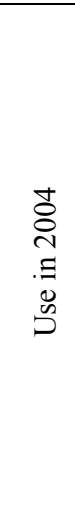 } & Class & FLO & AGR & NNFV & $\mathrm{AGU}$ & URB & OUT & FIF & Total \\
\hline & FLO & 1862.5 & 244.2 & 13.8 & 4.7 & 0.8 & 0.3 & 3.1 & 2129.4 \\
\hline & AGR & 178.1 & 645.1 & 4.7 & \multirow[t]{2}{*}{3.4} & \multirow[t]{3}{*}{1.6} & & \multirow[t]{5}{*}{0.3} & 833.1 \\
\hline & NNFV & 34.3 & 3.7 & 105.6 & & & & & 143.6 \\
\hline & $\mathrm{AGU}$ & 2.8 & 1.0 & & 27.3 & & & & 31.0 \\
\hline & URB & 0.4 & 0.1 & & & 4.7 & & & 5.1 \\
\hline & OUT & 0.2 & & & & & 0.7 & & 1.0 \\
\hline & FIF & 54.3 & 0.6 & & & & & 56.7 & 111.6 \\
\hline & Total & 2132.7 & 894.6 & 124.1 & 35.3 & 7.1 & 1.0 & 60.1 & 3254.9 \\
\hline & $\mathrm{C} 04 / 14\left(\mathrm{~km}^{2}\right)$ & 3.3 & 61.5 & -19.5 & 4.3 & 1.9 & 0.1 & -51.5 & \\
\hline & $*(\%)$ & 0.2 & 7.4 & -13.6 & 13.7 & 37.8 & 7.3 & -46.2 & \\
\hline
\end{tabular}

Considering the sum of FLO + FIF totals for $2004\left(2241 \mathrm{~km}^{2}\right)$ and $2014\left(2192.8 \mathrm{~km}^{2}\right)$, there was a reduction of $48.2 \mathrm{~km}^{2}(1.48 \%)$ in total forest area. In the two previous periods, reduction of forest areas reached $-6.6 \%$ (1984-1994), and -16.6\% (1994-2004), while the current period showed a reduction in deforestation rate of $-1.48 \%$. 2004 marked the beginning a decline in deforestation rates in the Amazon region as a result of institutional commitments aimed at reducing deforestation to minimum levels by 2020 (Brazil, 2015; MMA, 2015).

This period also recorded modest forest gains $\left(3.3 \mathrm{~km}^{2},-0.2 \%\right)$, in the FLO class, as a result of a reduction in fires (Figure 5) by $46.2 \%$ in the period. As noted in the 1998 to 2017 period, this facilitated the regeneration of the natural cover.

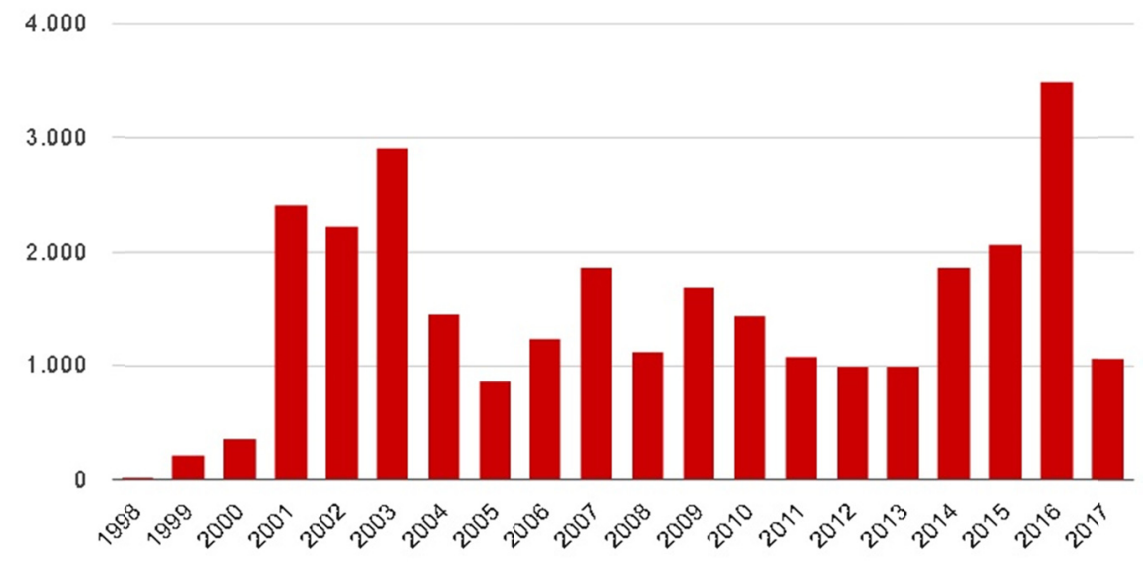

Figure 5. Number of fires in Roraima State between 1998 and 2017

Source: INPE (2017b).

\subsubsection{Land-Use Changes, 2014 to 2017}

In this period, the decline of the FLO class and the rise in the AGR class continued, with a reduction of $2.3 \%$ and a gain of 9.4\%, respectively (Table 7). Transitions between the FLO-AGR (5.8\%) and AGR-FLO (3.4\%) classes indicate, with a ratio of 1.7, that greater FLO-FIF conversion occurred. Transitions occurred in $12 \%$ of the mosaic. These changes were near-equally distributed among the classes of land use.

Also noteworthy was the continuation of the regeneration process in $5.4 \%$ of FIF areas, and a strong decline in the NNFV class (-24.9\%), a value that surpassed all previous recorded transitions, up to 2004. The decreases of 
$-7.2 \%$ and $-13.6 \%$ in 2014 , indicate a recent initiation of human activities in these areas of processes that previously focused more on forest areas, and only recently have begun occur in the savanna.

Table 7. Transition Matrix for land-use between 2014 and 2017 (area in $\mathrm{km}^{2}$ )

\begin{tabular}{|c|c|c|c|c|c|c|c|c|c|}
\hline Year & Use in 2017 & & & & & & & & \\
\hline \multirow{11}{*}{ 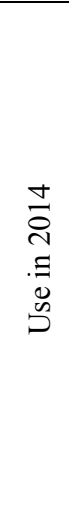 } & Class & FLO & AGR & NNFV & $\mathrm{AGU}$ & URB & OUT & FIF & Total \\
\hline & FLO & 1919.5 & 189.3 & 10.7 & 3.6 & 0.4 & 0.2 & 9.1 & 2132.9 \\
\hline & AGR & 110.9 & 780.2 & 1,0 & 1.8 & 0.6 & & & 894.6 \\
\hline & NNFV & 36.3 & 6.3 & 81.5 & & & & & 124.1 \\
\hline & AGU & 5.1 & 1.9 & & 29.2 & & & & 36.2 \\
\hline & URB & 0.2 & 0.3 & & & 6.5 & & & 7.1 \\
\hline & OUT & 0.3 & 0.1 & & & 0.1 & 0.6 & & 1.0 \\
\hline & FIF & 12.0 & 0.4 & & & & & 47.7 & 60.1 \\
\hline & Total & 2084.3 & 978.6 & 93.2 & 34.6 & 7.6 & 0.8 & 56.8 & 3256.0 \\
\hline & $\mathrm{C} 04 / 14\left(\mathrm{~km}^{2}\right)$ & -48.6 & 84.1 & -30.9 & -1.6 & 0.5 & -0.2 & -3.2 & \\
\hline & $*(\%)$ & -2.3 & 9.4 & -24.9 & -4.5 & 7.1 & -18.5 & -54 & \\
\hline
\end{tabular}

\subsubsection{Land-Use Changes, 1984 to 2017}

Across the 33 years analyzed, the classes Natural Non-forest Vegetation (NNFV) and Forest (FLO) declined most strongly in transitional areas, $39.3 \%$ and $23.8 \%$, respectively (Table 8 ).

The rate at which forested areas changed to agricultural use (TRFA) was 6.4 times greater than the rate of forest regeneration, highlighting the difference in rhythm between the processes of human-impact and spontaneous forest recovery. Transitions between these classes accounted for $85.2 \%$ of all recorded changes, indicating the regional prevalence of this form of land-use conversion (Fearnside \& Barbosa, 1988; Rittl, Oliveira, \& Cerri, 2017).

The ratio between the conversions (FLO-FIF) and (FIF-FLO) was calculated (TRFLO_FIF) in Note of Table 8 and reveals that in 33 years of landscape observations, approximately 39 times more anthropogenic processes occurred than the natural regeneration of the forests affected by the fire, to the observed initial condition. It also shows the drastic effect of the frequent fire regime under the forest environment, whose recent studies still seek to fill gaps and indices capable of measuring fire impacts on the regeneration mechanisms of Amazonian forests (Balch et al., 2013; Mesquita et al., 2015), specifying better the rhythm and variables involved in the trajectory of the decline of forest resilience.

The regional road network was upgraded and showed a $151 \%$ expansion in the period, with $361 \mathrm{~km}$ and 906.4 $\mathrm{km}$ of roads, respectively, in 1984 and 2017. Opening of roads stimulated both growth in urban areas, and the expansion of agricultural and livestock activities, which showed a combined growth of $199.5 \%$ over this period. However, this scenario also favors the conversion of forests, imposes threats to biodiversity, and a reduction and loss of genetic patrimony (Barlow et al., 2016).

The class NNFV which, in 1984 occupied $153.7 \mathrm{~km}^{2}$, was reduced in 2017 to $93.2 \mathrm{~km}^{2}$, an accumulated loss of $39.3 \%$, with $62 \mathrm{~km}^{2}$ converted to Forest, and $10.3 \mathrm{~km}^{2}$ to agriculture.

However, the currently observed FLO-NNFV and NNFV-FLO transitions could not have happened recently, given the complexity of the existing features and their spatial arrangement in the eco-environment in which they exist. Consequently, forest contraction and expansion during the Quaternary (Feitosa, Vale Júnior, Schaefer, Sousa, \& Nascimento, 2016) could provide a model for the temporal behavior of such transitional areas currently present within in the savannas, though, the subject requires further studies. Couto-Santos, Luizão, \& Carneiro Filho (2014) also observed a positive correlation between rainfall regime and the transitional behavior between forest and savanna areas in Roraima State. 
Table 8. Transition Matrix for land-use between 1984 and 2017 (area in $\mathrm{km}^{2}$ )

\begin{tabular}{|c|c|c|c|c|c|c|c|c|c|}
\hline Year & Use in 2017 & & & & & & & & \\
\hline \multirow{11}{*}{ 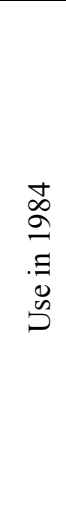 } & Class & FLO & AGR & NNFV & $\mathrm{AGU}$ & URB & OUT & FIF & Total \\
\hline & FLO & 1897.0 & 767.3 & 11.5 & 4.0 & 3.6 & 0.2 & 50.5 & 2734.0 \\
\hline & AGR & 119.7 & 200.6 & 0.4 & 3.3 & 2.5 & 0.2 & & 326.7 \\
\hline & NNFV & 62.0 & 10.3 & 81.4 & 0.0 & & & & 153.7 \\
\hline & $\mathrm{AGU}$ & 4.1 & 0.2 & & 27.1 & & & & 31.3 \\
\hline & URB & 0.1 & 0.1 & & & 1.5 & & & 1.6 \\
\hline & OUT & 0.1 & & & & & 0.4 & & 0.5 \\
\hline & FIF & 1.3 & 0.1 & & & & & 6.4 & 7.8 \\
\hline & Total & 2084.2 & 978.6 & 93.2 & 34.4 & 7.6 & 0.8 & 56.8 & 3255.7 \\
\hline & C $84 / 17\left(\mathrm{~km}^{2}\right)$ & -649.8 & 651.9 & -60.5 & 3.1 & 5.9 & 0.3 & 49.0 & \\
\hline & $*(\%)$ & -23.8 & 199.5 & -39.3 & 9.8 & 360.1 & 63.1 & 627.1 & \\
\hline
\end{tabular}

Note. $\mathrm{TRFA}=\mathrm{FA} / \mathrm{AF} ; \mathrm{FA}=(767.3 / 3255.7) ; \mathrm{AF}=(119.7 / 3255.7)$ and TRFA $=6.4 . \% \mathrm{TRFA}=[(100-(\mathrm{FA}+$ $\mathrm{AF})]=85.2 \%$. TRFLO-FIF $=($ FLO-FIF $) /($ FIF-FLO $)=\mathrm{FLO}-\mathrm{FIF}=(50.5) /(3255.7) ; \mathrm{FIF}-\mathrm{FLO}=(1.3) /(3255.7) ;$ TRFLO-FIF $=39,8$ or $\cong 39$.

\section{Conclusions}

In Roraima, the hypothesis of increasing anthropic pressure towards the ecotonal area was confirmed, focusing on the conversion of the forests to agricultural activity $\left(767.3 \mathrm{~km}^{2}\right)$ and specifically, on the FLO-NNFV (11.5 $\mathrm{km}^{2}$ ) and NNFV-FLO $\left(62 \mathrm{~km}^{2}\right)$, with alternating regeneration between classes. The intensity and recurrence of fire across the forested zone, determined the emergency of new land use class: forests impacted by fire (FIF). Although occupying less than $2 \%$ of all types of land use overall, FIF obtained strong growth (627\%), at the ratio of 39 times more anthropic conversions (FLO-FIF) than those observed in the regeneration (FIF-FLO). With 33 years of observation, intense fire regime became a key contributor to the decline of resilience of the remaining forests. We believe that further research is needed in Roraima to assess land use changes and the effect of fire on the regeneration mechanisms of regional forests.

\section{References}

Aguiar, P. D., Vieira, I. C. G., Assis, T. O., Dalla-Nora, E. L., Toledo, P. M., Santos-Junior, R. A. O., ... Ometto, J. P. H. (2016). Land use change emission scenarios: Anticipating a forest transition process in the Brazilian Amazon. Global Change Biology, 22(5), 1821-1840. https://doi.org/10.1111/gcb.13134

Almeida, A. L. O., \& Campari, J. S. (1995). Sustainable Settlement in the Brazilian Amazon (1st ed.). New York, USA: Oxford University Press, Inc.

Almeida, C. A., Coutinho, A. C., Esquerdo, J. C. D. M., Adami, M., Venturieri, A., Diniz, C. G., ,. Gomes, A. R. (2016). High spatial resolution land use and land cover mapping of the Brazilian Legal Amazon in 2008 using Landsat-5/TM and MODIS data. Acta Amazonica, 46(3), 291-302. https://doi.org/10.1590/1809-43 92201505504

Anderson, A. B. (1981). White-sand vegetation of Brazilian Amazonia. Biotropica, 13(3), 199-210. https://doi.org/10.2307/2388125

Balch, J. K., Massad, T. J., Brando, P. M., Nepstad, D. C., \& Curran, L. M. (2013). Effects of high-frequency understorey fires on woody plant regeneration in southeastern Amazonian forests. Philosophycal Transactions of the Royal Society B Biological Science, 368(1619), 20120157. http://doi.org/10.1098/ rstb.2012.0157

Barbosa, R. I. (1997). Distribuição das chuvas em Roraima. In R. I. Barbosa, E. J. G. Ferreira, \& E. G. Castellón (Eds.), Homem, Ambiente e Ecologia no Estado de Roraima (pp. 325-335). Manaus, Brasil: INPA.

Barbosa, R. I., \& Campos, C. (2011). Detection and geographical distribution of clearing areas in the savannas ('lavrado') of Roraima using Google Earth web tool. Journal of Geography and Regional Planning, 4(3), 122-136. Retrieved from http://www.academicjournals.org/JGRP

Barbosa, R. I., \& Fearnside, P. M. (1999). Incêndios na Amazônia Brasileira : Estimativa da emissão de gases do efeito estufa pela queima de diferentes ecossistemas de Roraima na passagem do evento "El Niño" 
(1997/98). Acta Amazonica, 29(4), 513-534. https://doi.org/10.1590/1809-43921999294534

Barbosa, R. I., \& Fearnside, P. M. (2000). Erosão do solo na Amazônia: Estudo de caso na região do Apiaú, Roraima, Brasil. Acta Amazonica, 30(4), 601-613. https://doi.org/10.1590/1809-43922000304613

Barbosa, R. I., \& Fearnside, P. M. (2005). Fire frequency and area burned in the Roraima savannas of Brazilian Amazonia. Forest Ecology and Management, 204(2-3), 371-384. https://doi.org/10.1016/j.foreco.2004. 09.011

Barlow, J., Lennox, G. D., Ferreira, J., Berenguer, E., Lees, A. C., Nally, R. Mac, ... Gardner, T. A. (2016). Anthropogenic disturbance in tropical forests can double biodiversity loss from deforestation. Nature, 535(7610), 144-147. https://doi.org/10.1038/nature18326

Barni, P. E., Pereira, V. B., Manzi, A. O., \& Barbosa, R. I. (2015). Deforestation and forest fires in Roraima and their relationship with phytoclimatic regions in the Northern Brazilian Amazon. Environmental Management, 55(5), 1124-1138. https://doi.org/10.1007/s00267-015-0447-7

Barros, D. S., Santos, C. S. V., Melo, V. F., \& Lopes, G. N. (2008). Mapeamento e caracterização ambiental das áreas apícolas do município de Mucajaí e Cantá do Estado de Roraima.Agro@mbiente On-line, 2(1), 77-87. Retrieved from: https://revista.ufrr.br/agroambiente/article/view/164/94

Brazil (Federative Republic of Brazil). (2015). Intended nationally determined contribution: Towards achieving the objective of the United Nations Framework Convention on Climate Change. http://www4.unfccc.int/ submissions/INDC/Published\%20Documents/Brazil/1/BRAZIL\%20iNDC\%20english\%20FINAL.pdf

Card, D. H. (1982). Using know map category marginal frequencies to improve estimates of thematic map accuracy. Photogrammetry Engineering and Remote Sensing, 48(3), 432-439.

Cerri, C. E. P., Abbruzzini, T. F., Brandani, C. B., Durigan, M. R., Freitas, R. C. A., Lisboa, I. P., ... Signor, D. (2015). Estoques de carbono e fluxo de gases do efeito estufa em agrossistemas no Brasil. Tópicos em Ciência do Solo, 9, 1-49.

CGMA (Coordenação Geral de Monitoramento e Avaliação de Políticas Regionais). (2015). Retrieved November 30, 2017, from http://sit.mda.gov.br/download/caderno/caderno_territorial_217_Centro-RR.pdf

Chávez Michaelsen, A., Perz, S. G., Huamani Briceño, L., Fernandez Menis, R., Bejar Chura, N., Moreno Santillan, R., ... Brown, I. F. (2017). Effects of drought on deforestation estimates from different classification methodologies: Implications for REDD+ and other payments for environmental services programs. Remote Sensing Applications: Society and Environment, 5, 36-44. https://doi.org/10.1016/j.rsase. 2017.01 .003

Clark, M. L. (2017). Comparison of simulated hyperspectral HyspIRI and multispectral Landsat 8 and Sentinel-2 imagery for multi-seasonal, regional land-cover mapping. Remote Sensing of Environment, 200, 311-325. https://doi.org/10.1016/j.rse.2017.08.028

Congalton, R. G. (1991). A review of assessing the accuracy of classifications of remotely sensed data. Remote Sensing of Environment, 37(1), 35-46. https://doi.org/10.1016/0034-4257(91)90048-B

Couto-Santos, F. R., Luizão, F. J., \& Carneiro Filho, A. (2014). The influence of the conservation status and changes in the rainfall regime on forest-savanna mosaic dynamics in Northern Brazilian Amazon. Acta Amazonica, 44(2), 197-206. https://doi.org/10.1590/S0044-59672014000200005

Davidson, E. A., De Araujo, A. C., Artaxo, P., Balch, J. K., Brown, I. F., Bustamante, M. M. C., ... Wofsy, S. C. (2012). The Amazon basin in transition. Nature, 481, 321-328. https://doi.org/10.1038/nature10717

Diniz, F. H., Kok, K., Hott, M. C., Hoogstra-Klein, M. A., \& Arts, B. (2013). From space and from the ground: Determining forest dynamics in settlement projects in the Brazilian Amazon. International Forestry Review, 15(4), 442-455. https://doi.org/10.1505/146554813809025658

EMBRAPA (Empresa Brasileira de Pesquisa Agropecuária). (2011). In J. F. Fialho \& E. A. Vieira (Eds.), Mandioca no Cerrado: Orientações Técnicas. Brasília, DF: EMBRAPA. Retrieved from http://www. infoteca.cnptia.embrapa.br/infoteca/handle/doc/981357

Fearnside, P. M. (1987). Frenesi de Desmatamento no Brasil: A floresta amazônica irá sobreviver? In G. Kohlhepp, \& A. Schrader (Eds.), Homem e Natureza na Amazônia (pp. 45-57). Tübinger Geographische Studien 95. Tübingen, Germany: Geographisches Institut, Universität Tübingen.

Fearnside, P. M. (2017). Deforestation of the Brazilian Amazon. In H. Shugart (Ed.), Oxford Research 
Encyclopedia of Environmental Science (Vol. 1). New York: Oxford University. https://doi.org/10.1093/ acrefore/9780199389414.013.102

Fearnside, P., \& Barbosa, S. (1988). Soil carbon changes from conversion of forest to pastures in Brazilian Amazonia. Forest Ecology, 108(1-2), 147-166. https://doi.org/10.1016/S0378-1127(98)00222-9

Feitosa, K. K. A., Vale Júnior, J. F., Schaefer, C. E. G. R., Sousa, M. I. L., \& Nascimento, P. P. R. R. (2016). Relações solo-vegetação em "ilhas" florestais e savanas adjacentes, no Nordeste de Roraima. Ciência Florestal, 26(1), 135-146. https://doi.org/10.5902/1980509821098

Gustavsson, L., Haus, S., Lundblad, M., Lundström, A., Ortiz, C. A., Sathre, R., ... Wikberg, P.-E. (2017). Climate change effects of forestry and substitution of carbon-intensive materials and fossil fuels. Renewable and Sustainable Energy Reviews, 67, 612-624. https://doi.org/10.1016/j.rser.2016.09.056

IBGE (Instituto Brasileiro de Geografia e Estatística). (2006). Bases de dados da Amazônia Legal com os temas geologia, geomorfologia, pedologia e vegetação. Retrieved March 10, 2015, from http://downloads.ibge. gov.br/downloads_geociencias.htm

IBGE (Instituto Brasileiro de Geografia e Estatística). (2011). Retrieved March 10, 2015, from http://downloads. ibge.gov.br/downloads_geociencias.htm

IBGE (Instituto Brasileiro de Geografia e Estatística). (2017). Retrieved November 30, 2017, from https://cidad es.ibge.gov.br/brasil/rr/mucajai/pesquisa/18/0?tipo $=$ grafico\&indicador $=16533$

INPE (Instituto de Pesquisas Espacias). (2004). Retrieved November 10, 2017, from http://www.dpi.inpe.br/prod esdigital/prodesmunicipal.php

INPE (Instituto de Pesquisas Espacias). (2017a). Retrieved from http://www.obt.inpe.br/OBT/assuntos/rogramas/ amazonia/prodes

INPE (Instituto de Pesquisas Espacias). (2017b). Retrieved October 7, 2017, from http://www.inpe.br/queimad as/estatistica_estados

IPCC (Intergovernmental Panel On Climate Change). (2007). In R. K. Pachauri, \& A. Reisinger (Eds.), Synthesis Report. Contribuition of Working Groups I, II and II to the Fourth Assessment Report of the Intergovemmental Panel Climate Change. Geneva, Switzerland: IPCC. Retrived from http://www.ipcc.ch/ publications_and_data/publications_ipcc_fourth_assessment_report_synthesis_report.htm

Jakimow, B., Griffiths, P., van der Linden, S., \& Hostert, P. (2018). Mapping pasture management in the Brazilian Amazon from dense Landsat time series. Remote Sensing of Environment, 205, 453-468. https://doi.org/10.1016/j.rse.2017.10.009

Kirby, K. R., Laurance, W. F., Albernaz, A. K., Schroth, G., Fearnside, P., Berger, S., ... da Costa, C. (2006). The future of deforestation in the Brazilian Amazon. Futures, 38(4), 432-453. https://doi.org/10.1016/ j.futures.2005.07.011

Lambin, E. F., Turner, B. L., Geist, H. J., Agbola, S. B., Angelsen, A., Bruce, J. W., ... Xu, J. (2001). The causes of land-use and land-cover change: Moving beyond the myths. Global Environmental Change, 11(4), 261-269. https://doi.org/10.1016/S0959-3780(01)00007-3

Lameira, O. A., \& Coimbra, J. M. (1988). Levantamento e distribuição da precipitação em Roraima (Boletim de Pesquisa $\left.{ }^{\circ} 12\right)$. Boa Vista, Roraima: EMBRAPA-UEPAT/BV-RR.

Landis, J. R., \& Koch, G. G. (1977). The measurement of observer agreement for categorical data. Biometrics, 33(1), 159-174. Retrieved from http://www.jstor.org/stable/2529310

Lathuillière, M. J., Miranda, E. J., Bulle, C., Couto, E. G., \& Johnson, M. S. (2017). Land occupation and transformation impacts of soybean production in Southern Amazonia, Brazil. Journal of Cleaner Production, 149, 680-689. https://doi.org/10.1016/j.jclepro.2017.02.120

Laurance, W. F. (2007). Ecosystem decay of Amazonian forest fragments: Implications for conservation. In T. Tscharntke, C. Leuschner, M. Zeller, E. Guhardja, \& A. Bidin, (Eds.), Stability of Tropical Rainforest Margins (pp. 11-37). Environmental Science and Engineering (Environmental Science). Heidelberg, Berlin: Springer. https://doi.org/10.1007/978-3-540-30290-2_2

Laurance, W. F., Albernaz, A. K. M., Schroth, G., Fearnside, P. M., Bergen, S., Venticinque, E. M., ... Da Costa, C. (2002). Predictors of deforestation in the Brazilian Amazon. Journal of Biogeography, 29(5-6), 737-748. https://doi.org/10.1046/j.1365-2699.2002.00721.x 
Ludewigs, T., D’antona, A. O., Brondízio, E. S., \& Hetrick, S. (2009). Agrarian structure and land-cover change along the lifespan of three colonization areas in the Brazilian Amazon. World Development, 37(8), 1348-1359. https://doi.org/10.1016/j.worlddev.2008.08.018

Melo, V. F., Francelino, M. R., Fernandes Filho, E. I., \& Schaefer, C. E. G. R. (2005). Unidades geoambientais da região do Apiaú, Roraima. Boletim do Museu Paraense Emílio Goeldi. Série Ciências Naturais, 1(2), 127-138.

Melo, V. F., Schaefer, C. E. G. R., Fontes, L. E. F., Chagas, A. C., \& Lemos Júnior, J. B. (2006). Caracterizacão física, química e mineralógica de solos da colônia agrícola do Apiaú (Roraima, Amazônia), sob diferentes usos e após queima. Revista Brasileira de Ciencia do Solo, 30(6), 1039-1050. https://doi.org/10.1590/ S0100-06832006000600013

Mesquita, R. C. G., Massoca, P. E. S., Jakovac, C. C., Bentos, T. V., \& Williamson, G. B. (2015). Amazon rain forest succession: Stochasticity or land-use legacy? BioScience, 65(9), 849-861. https://doi.org/10.1093/ biosci/biv108

Meyfroidt, P., Lambin, E. F., Erb, K.-H., \& Hertel, T. W. (2013). Globalization of land use: Distant drivers of land change and geographic displacement of land use. Current Opinion in Environmental Sustainability, 5(5), 438-444. https://doi.org/10.1016/j.cosust.2013.04.003

MMA (Ministério do Meio Ambiente). (2010). Retrieved December 17, 2017, from http:/www.florestal.gov.br/ documentos/acesso-informacao/institucional/cgflop/500-tp-3-polos-madeireiros/file

MMA (Ministério do Meio Ambiente). (2010). Retrieved December 17, 2017, from http://www.mma.gov.br/ images/arquivo/80120/PPCDAm/_FINAL_PPCDAM.PDF

MMA (Ministério do Meio Ambiente). (2010). Retrieved December 17, 2017, from http://simat.mma.gov.br/ acomweb/Media/Documentos/681501e5-2a88-40c1-a.pdf

Mourão, G. M. N. (2008). Colonização recente no sudeste de Roraima, Amazonia Brasileira: Entre a política e a natureza. Acta Geográfica, 4, 31-39. https://doi.org/10.5654/actageo2008.0204.0003

Nepstad, D. C., Veríssimo, A., Alencar, A., Nobre, C., Lima, E., Lefebvre, P., .. Brooks, V. (1999). Large-scale impoverishment of amazonian forests by logging and fire. Nature, 398(6727), 505-508. https://doi.org/ $10.1038 / 19066$

Nobre, C. A., Sampaio, G., Borma, L. S., Castilla-Rubio, J. C., Silva, J. S., \& Cardoso, M. (2016). Land-use and climate change risks in the Amazon and the need of a novel sustainable development paradigm. Proceedings of the National Academy of Sciences, 113(39), 10759-10768. https://doi.org/10.1073/pnas. 1605516113

Ogle, S. M., Olander, L., Wollenberg, L., Rosenstock, T., Tubiello, F., Paustian, K., ... Smith, P. (2014). Reducing greenhouse gas emissions and adapting agricultural management for climate change in developing countries: Providing the basis for action. Global Change Biology, 20(1), 1-6. https://doi.org/10.1111/gcb.12361

RADAMBRASIL. (1975). Projeto RADAMBRASIL-Levantamento dos recursos naturais (Vol. 8). Rio de Janeiro, Brasil: Ministério do Meio Ambiente, Ministério das Minas e Energia.

Rittl, T. F., Oliveira, D., \& Cerri, C. E. P. (2017). Soil carbon stock changes under different land uses in the Amazon. Geoderma Regional, 10, 138-143. https://doi.org/10.1016/j.geodrs.2017.07.004

Schaefer, C. E. G. R. (1997). Ecogeography and human scenario in Northeast Roraima, Brazil. Ciência e Cultura, 49(4), 241-252.

Vieira, S., Trumbore, S., Camargo, P. B., Selhorst, D., Chambers, J. Q., Higuchi, N., \& Martinelli, L. A. (2005). Slow growth rates of Amazonian trees: consequences for carbon cycling. Proceedings of the National Academy of Sciences of the United States of America, 102(51), 18502-18507. https://doi.org/10.1073pnas. 0505966102

WRB, I. W. G. (2014). World Reference Base for Soil Resources 2014, Update 2015 International Soil Classification System for Naming Soils and Creating Legends for Soil Maps (World Soil Resources Reports No. 106). Rome: FAO.

Xaud, M. R. (2013). Dinâmica do uso e cobertura da terra na região sudeste de roraima através de técnicas de detecção de mudança (Doctoral dissertation, São José dos Campos, São Paulo, Brasil). Retrived from http://urlib.net/8JMKD3MGP7W/3DRR8MH 
Zarin, D. J., Harris, N. L., Baccini, A., Aksenov, D., Hansen, M. C., Azevedo-Ramos, C., ... Tyukavina, A. (2016). Can carbon emissions from tropical deforestation drop by $50 \%$ in 5 years? Global Change Biology, 22(4), 1336-1347. https://doi.org/10.1111/gcb.13153

\section{Copyrights}

Copyright for this article is retained by the author(s), with first publication rights granted to the journal.

This is an open-access article distributed under the terms and conditions of the Creative Commons Attribution license (http://creativecommons.org/licenses/by/4.0/). 